Патинська-Попета М. М., аспірант

Поліський національний університет м. Житомир, Украӥна

DOI: https://doi.org/10.30525/978-9934-26-068-1-17

\title{
ФОРМУВАННЯ ЛЮДСЬКОГО ПОТЕНЦАЛУ ЯК ФАКТОР СТАЛОГО РОЗВИТКУ ТЕРИТОРІАЛЬНИХ ГРОМАД
}

Сучасні світові тенденції створення соціально орієнтованої ринкової економіки, відновлення біполярного глобального суспільного устрою, утвердження ідеології людиноцентризму обумовлюють необхідність здійснення в Україні демократичних змін.

Стратегією сталого розвитку «Україна - 2020» (2015 р.) задекларовано впровадження в Україні європейських стандартів життя [2]. Оцінка рівня життя та якості населення країн світу визначається за Індексом людського розвитку (ІЛР), розробленим Програмою розвитку Організації Об'єднаних Націй (ПРООН) у 1990 р. Система розрахунку ІЛР включає аналіз і моніторинг трьох показників:

- рівень життя (оцінений через валовий національний дохід (ВНД) на душу населення);

- рівень грамотності населення (очікувана тривалість навчання);

- оцінка довголіття (очікувана тривалість життя).

За даними ПРООН, за період 1990-2020 рр. значення ІЛР України зросло від 0,705 до 0,779 . За цим показником Українська держава у 2020 р. посіла 74 місце зі 189 країн і територій, піднявшись на 14 позицій в ІЛР, що робить іiі належною до країн високого рівня людського розвитку [4].

У сучасних умовах глобалізації та євроінтеграції України важлива роль належить досягненню сталого територіального розвитку: підвищенню освітнього рівня населення, покращенню медичного обслуговування, удосконаленню механізмів 
соціального захисту населення, розвитку культури, що $\epsilon$ вагомими чинниками формування інтелектуального потенціалу суспільства, його економічного зростання, збереження навколишнього природного середовища як для нинішніх, так i для майбутніх поколінь.

Українська держава обрала європейські стандарти організації місцевого самоврядування. У процесі адміністративно-територіальної реформи за період 2015 - 2020 рр. (на 10.02.21 р.) створено 1438 об'єднаних територіальних громад (ОТГ). У 1421 громаді відбулися чергові вибори [1]. Такі темпи міжмуніципальної консолідації міжнародні експерти називають дуже високими.

Однак на сьогодні наявна низка викликів на шляху реалізації реформи. Ключовими з них є завершення процесу децентралізації та створення сучасної системи територіальної організації влади. Ці фактори зумовлюють застосування нових ефективних інструментів управління в новостворених, укрупнених територіальних громадах, переходу від політики публічного адміністрування до застосування підходів менеджменту, які в публічному управлінні розвинутих країн сьогодні становлять одну 3 провідних складових його сучасної парадигми. Йдеться, зокрема, про формування людського потенціалу як вагомого чинника інноваційного розвитку територіальної громади, з урахуванням усіх його аспектів під час розробки та реалізації стратегій розвитку.

В умовах загроз i викликів, спричинених пандемією та соціально-економічною кризою, актуальність побудови нових стратегій управління процесами сталого територіального розвитку визначається аспектами, що відображають найвагоміші сучасні проблеми, від вирішення яких залежить, з одного боку, розвиток системи місцевого самоврядування як елементу демократії, з іншої забезпечення якості життя населення. Відтак важливого значення набуває розробка та впровадження інноваційних управлінських стратегій сталого розвитку громад із використанням провідного європейського досвіду та кращих практик. 
Концепція сталого розвитку передбачає, що людина повинна брати участь у процесах, які формують сферу їі життєдіяльності, сприяти прийняттю й реалізації рішень, контролювати їх виконання. Однак в Україні спостерігається низький рівень довіри між громадянами та місцевими органами влади, що зумовлено, з одного боку, неспроможністю органів місцевого самоврядування (ОМС) до фінансової відкритості перед громадою, корумпованістю чиновників та, 3 іншого боку, низькою зацікавленістю мешканців, їхньою необізнаністю в бюджетних процесах.

В умовах адміністративно-територіальної реформи становлення місцевого самоврядування як елементу громадянського суспільства потребує насамперед досягнення соціальної ефективності шляхом залучення громадян до участі у вирішенні проблем громад. Базовим елементом новітньої стратегії управління $є$ людиноцентрична модель, в основі якої лежить розвиток, спрямований на задоволення потреб та інтересів громадян. Водночас освічене, соціально адаптоване, конкурентоздатне населення має стати провідником та учасником процесу забезпечення спроможності територіальної громади, соціальнопсихологічного комфорту іï мешканців.

Складовою основного капіталу А. Сміт розглядав «набуті й корисні здібності всіх мешканців або членів суспільства». Такі здібності людини вимагають витрат на ii виховання та освіту. Водночас такі витрати «...є основою капіталу, який начебто реалізується в їі особистості. Ці здібності, будучи частиною статків такої особи, водночас стають частиною багатства всього суспільства, до якого воно належить» [3]. Ці положення теорії А. Сміта $є$ цінними в умовах упровадження особистісно орієнтованої моделі управління розвитком територій на засадах людиноцентризму, складовою якої $\epsilon$ створення достатнього освітнього середовища, формування нового громадянського мислення.

Учений Ф. Фукуяма стверджував, що соціальний капітал «це норми, неформальні норми або цінності, які роблять 
можливими колективні дії у групах людей» [6]. Йдеться про такі норми, як свідомий вибір управлінських рішень, їх доцільність, інноваційність в управлінні тощо.

Якість людського потенціалу територіальної громади науковці оцінюють за такими критеріями: готовність людських ресурсів до інноваційної діяльності; конкурентоспроможність робочої сили; наявність середнього класу, здатного впроваджувати результати наукових розвідок у реальне життя [5, с. 27].

Запровадження принципів розвитку людського потенціалу вимагає усталеної системи мотивації: громадянської свідомості, корпоративної культури, урахування колективістських традицій, особистої відповідальності за добробут територіальної громади, створення загального іміджу ОТГ.

Ефективне залучення людського потенціалу до процесів управління територіальним розвитком громад відповідно до особливостей населеного пункту, інтересів і потреб мешканців $є$ важливим чинником сталого розвитку громад. А одним із найефективніших заходів розвитку територіальної громади, як зазначають науковці та практики, $є$ інвестиції в розвиток людського капіталу.

\section{Література:}

1. Офіційний сайт прес-центру ініціативи «Децентралізація». URL: https://decentralization.gov.ua/about

2. Про Стратегію сталого розвитку «Україна - 2020» : Указ Президента України від 12 січня 2015 року № 5/2015. URL: https://zakon. rada.gov.ua/ laws/show/5/2015.

3. Сміт А. Добробут націй. Дослідження про природу і причини добробуту націй. Київ : Port-Royal, 2001. 590 с.

4. Україна значно покращила позиції в Індексі людського розвитку. URL: https://www.ukrinform.ua/rubric-society/3155117-ukraina-znacno-pokrasila-poziciiv-indeksi-ludskogo-rozvitku.html.

5. Управління розвитком людського потенціалу територіальної громади в інноваційно-знаннєвому суспільстві / Ю.О. Куц, В.В. Мамонова, С.В. Газарян. Київ : НАДУ, 2012. 44 с.

6. Фукуяма Ф. Що таке соціальний капітал? Київська лекція Френсіса Фукуями. День. 2006. № 177. URL: http://day.kyiv.ua/uk/article/podrobici/shchotake-socialniy-kapital. 